\title{
A Study of the Use of Some Medicinal Plants by Tribes Living in Jashpur District of Chhattisgarh State
}

\author{
Pramod Yadaw ${ }^{1}$, Shilpi Shrivastava ${ }^{2}$ \\ ${ }^{1}$ Research Scholar, Department of Chemistry, Kalinga University, Naya Raipur, (C.G.) India. ${ }^{2}$ Professor \& Dean of Science, Kalinga \\ University, Naya Raipur, (C.G.) India .
}

\begin{abstract}
Jashpur district is a herbal medicinal district of Chhattisgarh, where various tribes people like Korwa, Gond, Nageshiya, Birhor, Pando and Baiga are reside. The tribal people mostly obtain medicines from the forests and use them in large quantities for various diseases and sell the medicinal herbs in the market and make a living from that income. The survey revealed that most of these wild medicinal herbs are used by tribes in wide volumes for Fever, Skin diseases, Headache, Body pain, Joint pain, Bone fracture, Digestive problem, Piles and Paralysis. There are 100 of medicinal plant species available as medicines in Jashpur district.
\end{abstract}

Keywords - Traditional Medicinal Plants, Tribes, Jashpur.

\section{INTRODUCTION}

Jashpur district is a medicinal district of Chhattisgarh. It was clear from the study of living of tribal people of this district that the present time of more than 5,30,320 oraon, gond, nagesiya, pando, hill korwa, birhor and other tribal people reside in jashpur district. This is the basis of their living forest from where the tribal people get some Needs from the forests [1]. A large quantity of herbs is collected from the forests and for the treatment of various diseases by the local vaidyaraj's decoction of natural herbs medicine is made and given to the patient by grinding. This is not a medical system today. Since ancient times the tribal use the wild medicines and have the illnesses diagnosed.

According to the vaidyaraj's of some places during the survey of Jashpur district [2]. The medicinal plant obtained from the forests were used heavily for the treatment of various diseases such as fever, headaches, stomach pain, body pain, paralysis, dermatitis, miscarriage, weakness, typhoid, malaria, bone fracture,

*Address of Correspondence: Pramod Yadaw, Research Scholar, Department of Chemistry, Kalinga University, Naya Raipur, (C.G.) India. E-mail- pramodyadaw23@gmail.com (Received 29 September 2020; Revised 06 October 2020; Accepted 12 October 2020) 
cough, creamy, asthma, and blood pressure, sugar goes and by using these medicines, diseases of human body are being treated easily and it does not have any side effects on human body [3]. In habitant tribes mostly use natural methods for first aid in large quantities and are using the income derived from selling these wiles herbs in the markets for their livelihood [4].

\section{MATERIALS AND METHOS}

Some areas of Jashpur District Kansabel, Bagicha, Manora, Duldula, Tapkara and Pathalgaon survey made it clear that the local residents and local vaidyaray's collected herbs from the forests and used herbs and medicinal plant to cure various diseases being done [5]. The tribal people are using wild medicines in large quantity to cure various diseases at less time and less expense and giving priority to wild medicines I surveyed some medicinal areas of jashpur district from November 2019 to February 2020 during this time [6].The medicinal plant was collected and studied on the basis of its various properties and after interaction with the local vaidyaraja it became clear that the tribal people living here treat various diseases using various medicines and the tribes make huge use in the treatment of various diseases by making wild medicines decoction [7].

\section{RESULTS}

During the survey of medicinal plants in Jashpur district and according to the statement of local doctors, the tribal people have been using the medicinal plants traditionally for centuries [8]. A special quality of wild medicines is that if the disease is not cured, there is no toxic effect in the human body [9]. With no toxic effects on diseases, wild drugs are being used more and more as primary treatment by people in rural areas, as well as the importance and utility of wild medicine herbs will continue and by looking at the photographs and list of medicinal plants recorded in this research work, it will be helpful to get information about medicinal properties and further its usefulness [10].

Table 1: Collected medicinal plants species and medicinal uses

\begin{tabular}{|c|c|c|c|c|c|}
\hline S.N. & $\begin{array}{c}\text { Local } \\
\text { Name 0f } \\
\text { Plant }\end{array}$ & $\begin{array}{c}\text { Botanical } \\
\text { Name Of } \\
\text { Plant }\end{array}$ & Family & $\begin{array}{c}\text { Used Of } \\
\text { Plant Part }\end{array}$ & Medicinal Uses \\
\hline 1 & Goonj & $\begin{array}{c}\text { Abrus } \\
\text { precatori } \\
\text { us }\end{array}$ & Fabaceae & Root, Leaf & Itching, Skin disease \\
\hline 2 & Neem Giloy & $\begin{array}{c}\text { Tinospora } \\
\text { cordifolia }\end{array}$ & $\begin{array}{c}\text { Menisperm- } \\
\text { aceae }\end{array}$ & $\begin{array}{c}\text { Stem, Stem } \\
\text { barks }\end{array}$ & $\begin{array}{c}\text { Body pain, Typhoid, } \\
\text { Blood purification, } \\
\text { Malaria }\end{array}$ \\
\hline 3 & Aakh & $\begin{array}{c}\text { Calotropis } \\
\text { gigantea }\end{array}$ & $\begin{array}{c}\text { Apocynac- } \\
\text { eae }\end{array}$ & Flower, Latex & $\begin{array}{c}\text { Teeth pain, Wound } \\
\text { healing, Asthma }\end{array}$ \\
\hline 4 & Rahad & $\begin{array}{c}\text { Cajanus } \\
\text { cajan }\end{array}$ & $\begin{array}{c}\text { Fabaceae } \\
\text { Leaf, Seed }\end{array}$ & $\begin{array}{c}\text { Blood pressure, } \\
\text { Digestion, Nose bleed }\end{array}$ \\
\hline 5 & Mahua & Madhuca & Sapotaceae & Bark, Seed, & Headache, Diarrhea, \\
\hline
\end{tabular}




\begin{tabular}{|c|c|c|c|c|c|}
\hline & & longifolia & & Latex & Galva \\
\hline 6 & Munga & $\begin{array}{l}\text { Moringa } \\
\text { oleifera }\end{array}$ & Moringaceae & $\begin{array}{l}\text { Leaf, Fruit, } \\
\text { Root }\end{array}$ & $\begin{array}{c}\text { Blood pressure, Sugar, } \\
\text { Killing worm }\end{array}$ \\
\hline 7 & Sendhwar & $\begin{array}{c}\text { Vitex } \\
\text { negundo }\end{array}$ & Lamiaceae & Leaf, Oil & $\begin{array}{l}\text { Killing worm, Joint pain, } \\
\text { Body pain }\end{array}$ \\
\hline 8 & Pipal & $\begin{array}{l}\text { Ficus } \\
\text { religiosa } \\
\text { linn. }\end{array}$ & Moraceae & $\begin{array}{l}\text { Stem Bark, } \\
\text { Root bark }\end{array}$ & $\begin{array}{l}\text { Cuts, Snake-bite, } \\
\text { Diarrhea }\end{array}$ \\
\hline 9 & Bargad & $\begin{array}{l}\text { Ficus } \\
\text { benghale } \\
\text { nsis }\end{array}$ & Moraceae & $\begin{array}{l}\text { Stem bark, } \\
\text { Root bark, } \\
\text { Latex } \\
\end{array}$ & $\begin{array}{l}\text { Piles, Skin disease, } \\
\text { Ulcer, Diarrhea }\end{array}$ \\
\hline 10 & Bhasma & $\begin{array}{l}\text { Bryophyl- } \\
\text { lum }\end{array}$ & Crassulaceae & $\begin{array}{l}\text { Leaf and } \\
\text { Stem juice }\end{array}$ & Stone diseases \\
\hline 11 & Sadabahar & $\begin{array}{l}\text { Catharan- } \\
\text { thus }\end{array}$ & $\begin{array}{c}\text { Apocynace- } \\
\text { ae }\end{array}$ & Leaf & $\begin{array}{l}\text { Sugar, High blood } \\
\text { pressure, Mental } \\
\text { disorder }\end{array}$ \\
\hline 12 & Tendu & $\begin{array}{l}\text { Coroman } \\
\text { del ebony }\end{array}$ & Ebenaceae & Fruit, Bark & $\begin{array}{l}\text { Digestion problem, } \\
\text { Blood bile, Impotency }\end{array}$ \\
\hline 13 & Kosam & $\begin{array}{l}\text { Schleich- } \\
\text { era }\end{array}$ & Sapindaceae & Seeds oil & $\begin{array}{l}\text { Body pain, Cleaning } \\
\text { stomach }\end{array}$ \\
\hline 14 & Gulbakauli & $\begin{array}{l}\text { Hedychim } \\
\text { coronari- } \\
\text { um }\end{array}$ & $\begin{array}{l}\text { Zingiberace- } \\
\text { ae }\end{array}$ & Flower juice & Eye disease, Glaucoma \\
\hline 15 & Vantulsa & $\begin{array}{l}\text { lantana } \\
\text { camaral }\end{array}$ & Verbenaceae & Root, Leaf, Oil & Welling, Ulcer, Wounds \\
\hline 16 & $\begin{array}{c}\text { Meetha } \\
\text { neem }\end{array}$ & $\begin{array}{l}\text { Murraya } \\
\text { koenigii }\end{array}$ & Rutaceae & Leaves & Diabetes \\
\hline 17 & Chirchita & $\begin{array}{l}\text { Achyranh } \\
\text { es aspera }\end{array}$ & $\begin{array}{c}\text { Amaranthac } \\
\text { eae }\end{array}$ & Stem, Leaves & Bone fracture, Joint pain \\
\hline 18 & Bael & $\begin{array}{c}\text { Aegle } \\
\text { mormelos }\end{array}$ & Rutaceae & Fruit & $\begin{array}{c}\text { Digestion, Clean } \\
\text { stomach } \\
\end{array}$ \\
\hline 19 & Karanj & $\begin{array}{l}\text { Pongamia } \\
\text { pinnata }\end{array}$ & Fabaceae & Stem, Oil & $\begin{array}{l}\text { Ringworm, Itching, } \\
\text { Wound drying }\end{array}$ \\
\hline 20 & Kathal & $\begin{array}{l}\text { Artocarps } \\
\text { heteroph } \\
\text { yllus }\end{array}$ & Moraceae & $\begin{array}{l}\text { Fruit, Seeds, } \\
\text { Seed powder, } \\
\text { Root }\end{array}$ & $\begin{array}{c}\text { Liver problem, Blood } \\
\text { circulation, Cancer, } \\
\text { Heart problem, Fatness, } \\
\text { Asthma, }\end{array}$ \\
\hline
\end{tabular}




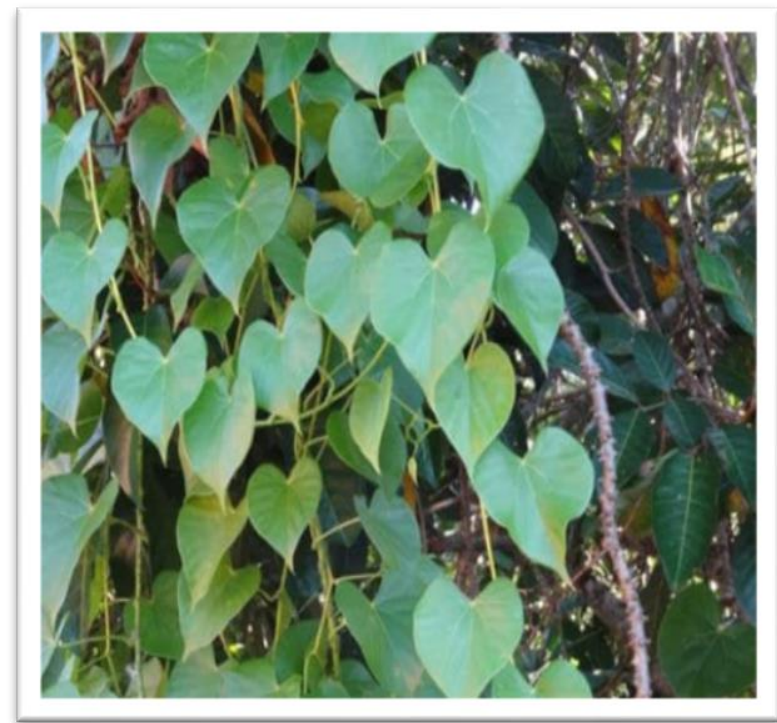

Figure 1: Tinospora cordifolia

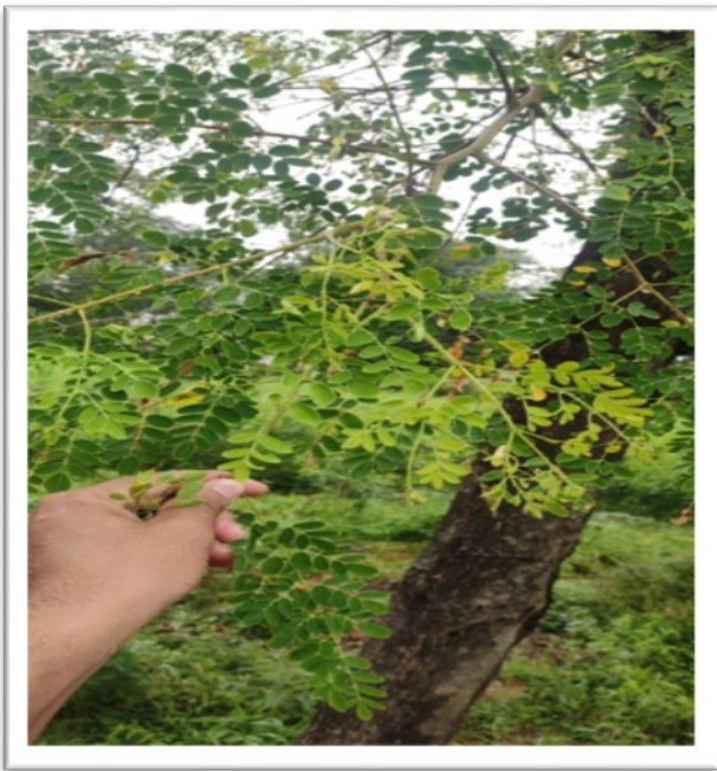

Figure 3: Moringa oleifera

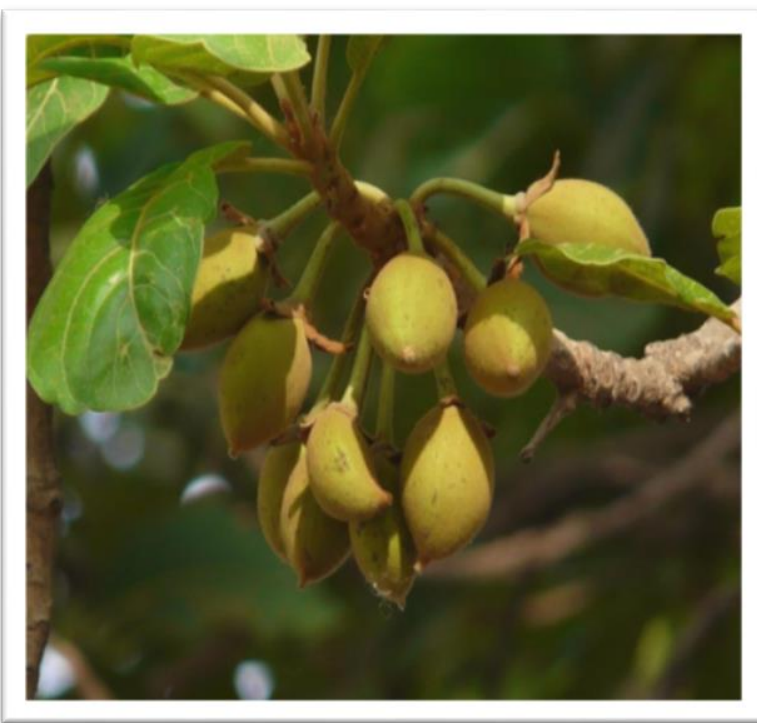

Figure 2: Madhuca longifolia

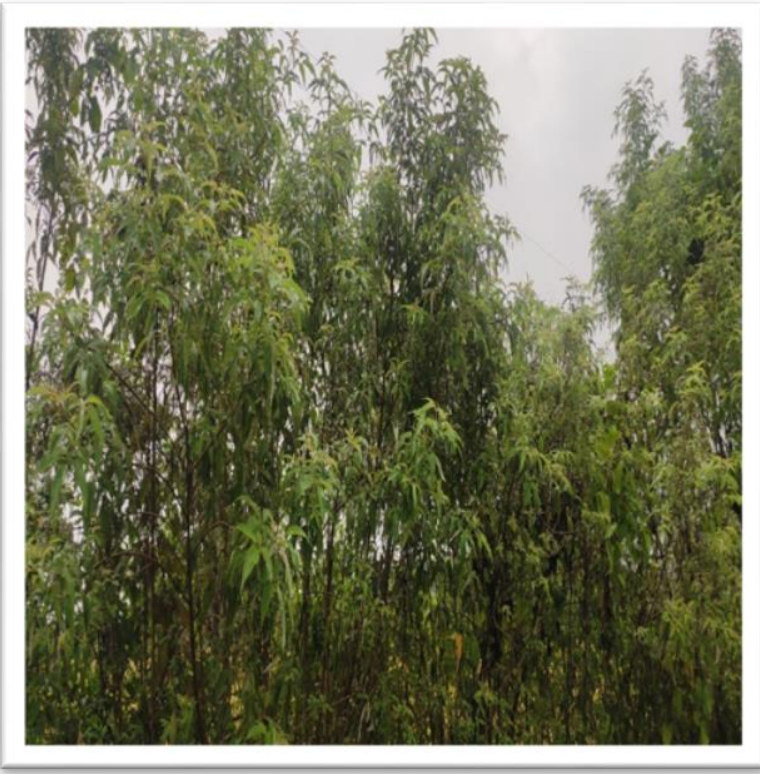

Figure 4: Vitex negundo 


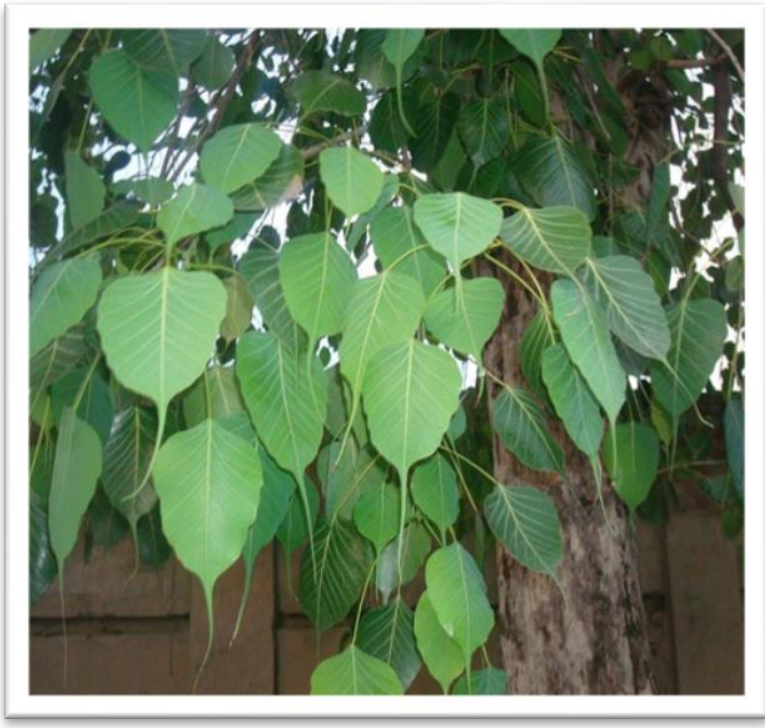

Figure 5: Ficus religiosa linn

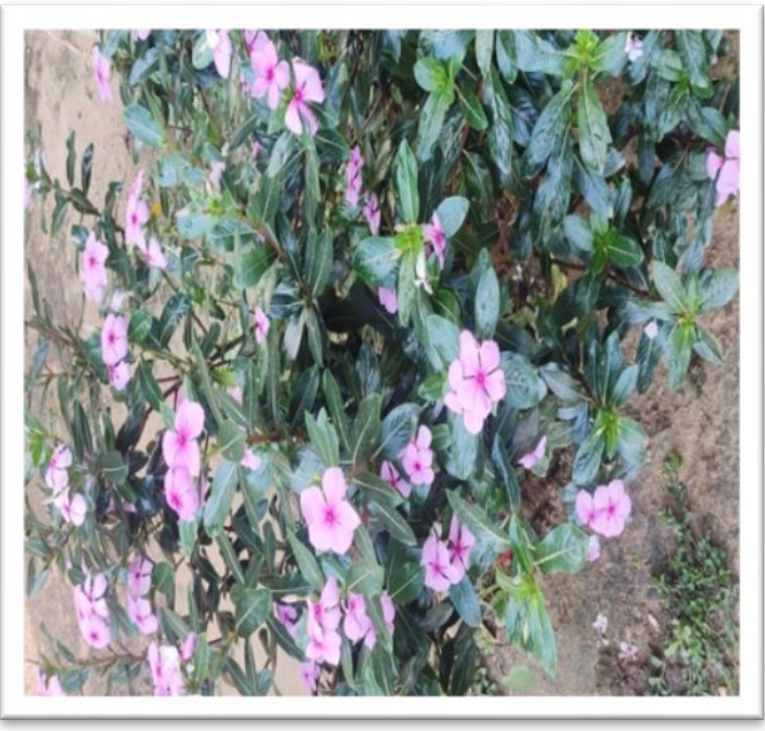

Figure 6: Catharanthus

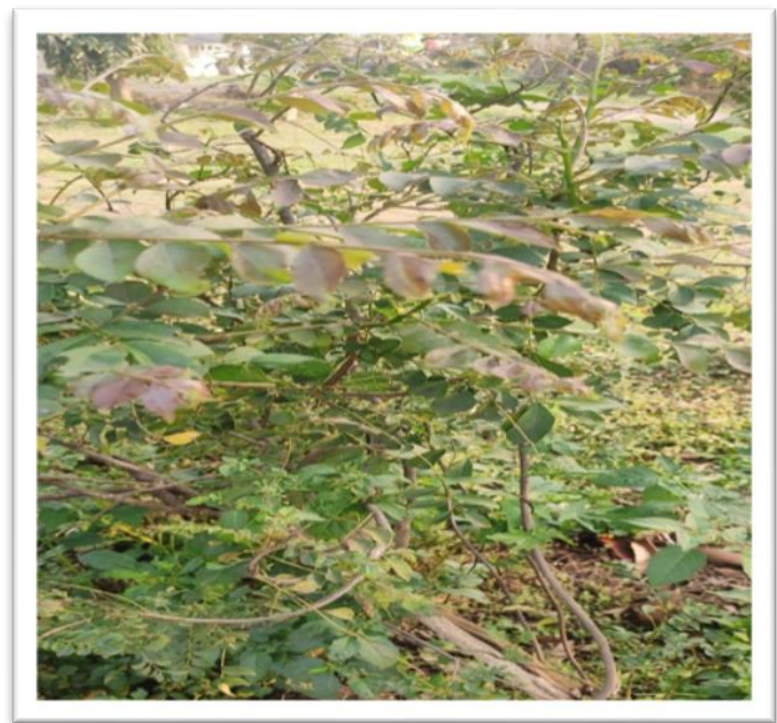

Figure 7: Murraya koenigii

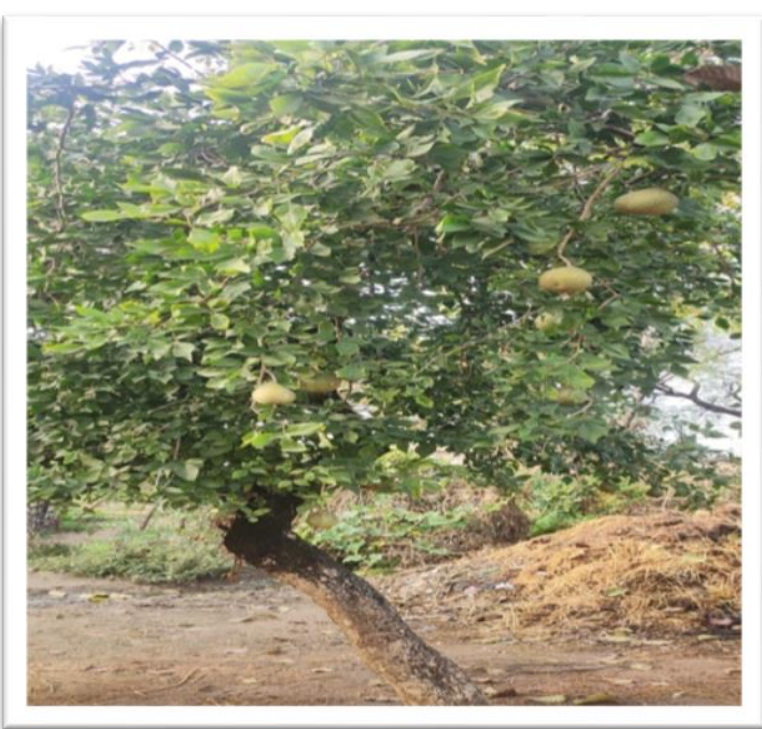

Figure 8: Aegle mormelos 


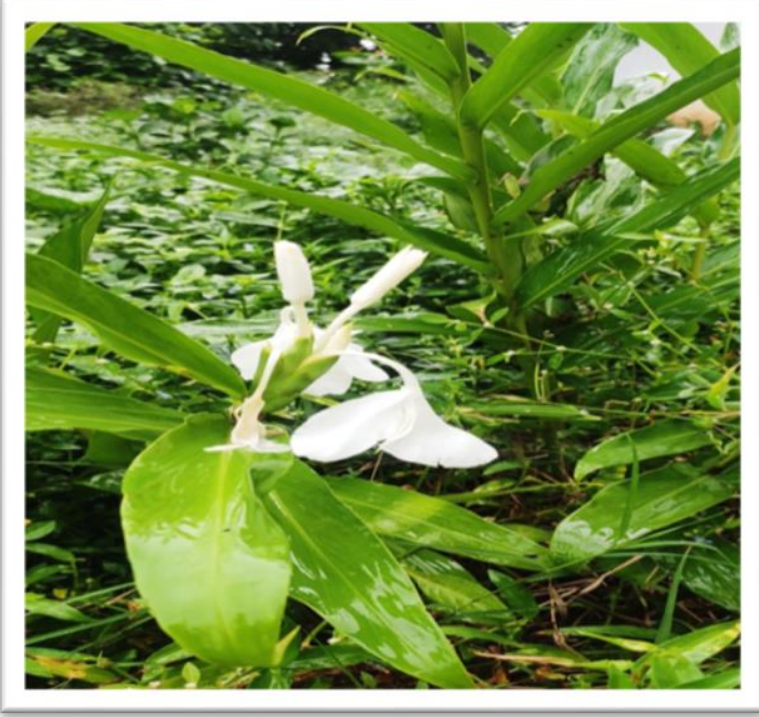

Figure 9: Artocarpus heterophyllus

\section{CONCLUSION}

Jashpur district is a tribal-dominated district, which has a half-life of the tribes residing here with its forests [11]. The study of some medicinal plants found in the Kansabel, Bagicha, Manora, Duldula, Tapkara and Pathalgaon region under Jashpur district made it clear that medicinal plants have special properties for curing diseases and according to the statements of tribes and non-tribes living in local areas From generation to date, medicinal plants have been used in first aid in various ways in the treatment, as well as local herbs have also been used by local to treat a variety of diseases.To cure numerous illnesses, he uses wil $\mathrm{d}$ plants widely as primary and herbal medicine. And regardless of the intake being cured, ther e are no side effects on human well-being. The survey made it clear that the use of medicinal plants is beneficial for the people of rural and urban areas. In the coming generations, these medicinal plants will be used.

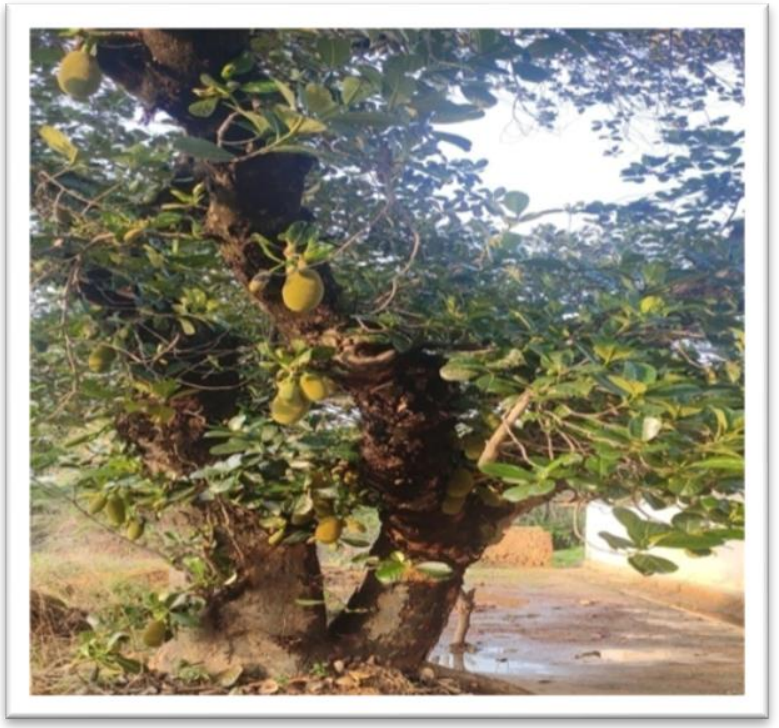

Figure 10: Hedychium coronarium

\section{ACKNOWLEDGEMENT}

I am from Pramod Yadaw Research Scholar Chemistry, Kalinga University Naya Raipur Chhattisgarh. My research guide as per the instruction of Dr. Shilpi Shrivastava, I completed this research work with the help of my wife Mrs. Geeta Yadav and my research friends and my tireless efforts in completing this research work. I will always be grateful to all the people who helped in my research work.

\section{CONFLICT OF INTEREST}

The authors have no conflict of interest regarding the research content of the article.

\section{REFERENCES}

1. Ekka A. Some rare plants used by hill - korwa in their healthcare from Chhattisgarh, International journal of life science biotechnology and pharma research. 2013; 2(1):198-203, ISSN: 2250-3137.

2. Biswas K, Chattopadhyay I, Banerjee RK and Bandyopadhyay U. Biological activities and 
medicinal properties of neem (Azadirachta indica). 2002; 82(11): 1336-1345.

3. Chatterjee AK. Study of ethno- medicinal plants among the tribals of surguja region (C.G.), International journal on advanced theory and engineering (IJACTE). 2014; 3(2): 56-60, ISSN: 2319-2526.

4. Ekka MK, Prasad H, Tiwari P. Traditional use of practiced by the oraon tribe of jashpur district (C.G.).India, IOSR journal of environmental science, toxicology and food technology (IOSRJESTFT). 2015; 1(1): 60-64, ISSN: 2319-2399.

5. Ekka A, Ekka NS. Traditional plants used for snakebite by oraon tribe of jashpur district, Chhattisgarh, International journal of advanced research in management and social scince. 2013; 2(6): 1-9, ISSN: 2278-6236.

6. Yadaw P, Shrivastava S. Properties and uses of some medicinal plants found in Jashpur district of Chhattisgarh. IOSR journal of applied chemistry (iosr-jac). 2019; 12(8): 51-54, ISSN (0): 2278-5736.

7. Kurre RK. Wide variety of medicinal plants and their uses in jashpur district of Chhattisgarh, IOSR journal of environmental science, toxicology and food technology (IOSR-JESTFT). 2015; 1(1): 01-05, e-ISSN : 2319-2402, p-ISSN : 2319-2399.
8. Kujur M, Ahirwar RK. Folklore claims on some ethno medicinal plants used by various tribes of district jashpur, Chhattisgarh, India, International journal of current microbiology and applied sciences. 2015; 4(9): 860-867, ISSN: 2319-7706.

9. Painkra VK, Jhariya MK, Raj A. Assessment of knowledge of medicinal plants and their use in tribal region of jashpur district of Chhattisgarh, India, Journal of applied and natural science. 2015; 7(1): 434-442, ISSN: 0974-9411(print), 2231-5209 (online).

10. Sharma R, Ekka A. Diversity of medicinal plants in pt. ravishankar shukla university campus, Raipur, Chhattisgarh, India, European journal of pharmaceutical and medical research. 2016; 3(3): 383-397, ISSN: 3294-3211.

11. Sharma RK. Study of ethnomedicinal plants by the oraon tribe of jashpur district (C.G.) india, International journal of botany studies. 2017; 2(6): 157-159, ISSN: 2455-541X. 